\title{
PENGARUH BRAND IMAGE DAN TRUST TERHADAP LOYALITAS PELANGGAN
}

\section{THE EFFECT OF BRAND IMAGE AND TRUST ON LOYALTY OF CUSTOMERS}

\author{
Zainal Abidin \\ Fakultas Ekonomi Universitas Abdurachman Saleh Situbondo
}

\begin{abstract}
ABSTRAK
Penelitian ini bertujuan untuk mengetahui pengaruh brand image dan trust terhadap loyalitas pelanggan pengguna kartu as telkomsel di Desa Pokaan Kecamatan Kapongan Kabupaten Situbondo. Populasi pada penelitian ini diketahui sebesar 685 pengguna kartu AS Telkomsel pada Desa Pokaan Kecamatan Kapongan Kabupaten Situbondo, jumlah sampel yang digunakan dalam penelitian ini sebanyak 87 responden, dengan kriteria melakukan pembelian minimal sebanyak 3 kali kartu As. Metode analisis mengunakan analisis regresi linier berganda. Hasil penelitian menunjukkan bahwa variabel truts berpengaruh secara signifikan positif terhadap loyalitas pelanggan. Variabel brand image mempunyai pengaruh signifikan positif terhadap loyalitas pelanggan.
\end{abstract}

Kata Kunci: brand image, trust, loyalitas pelanggan.

\begin{abstract}
This study aims to determine the effect of brand image and trust on customer loyalty of Telkomsel as card users in Pokaan Village, Kapongan District, Situbondo Regency. The population in this study was known to be 685 US card users of Telkomsel in Pokaan Village, Kapongan Subdistrict, Situbondo Regency, the number of samples used in this study was 87 respondents, with the criteria of purchasing at least 3 times the As card. The analytical method uses multiple linear regression analysis. The results showed that the truts variable had a significantly positive effect on customer loyalty. Brand image variables have a significant positive effect on customer loyalty.
\end{abstract}

Keywords: brand image, trust, customer loyalty.

\section{PENDAHULUAN}

Perkembangan teknologi dewasa ini membawa manusia untuk dapat melakukan segala hal secara instan. Salah satu contoh adalah dalam dunia komunikasi. Suratmenyurat tidaklah lagi menjadi satu-satunya jalan untuk melakukan komunikasi jarak jauh, handphone menjadi pilihan utama, selain bisa digunakan untuk komunikasi jarak jauh, dapat dibawa kemana-mana, handphone juga memiliki banyak kegunaan lain. Pemakainya semakin bertambah luas, boleh dikatakan setiap orang memakainya, seperti kebutuhan pokok, dengan kondisi semacam ini maka banyak pilihan SIM Card yang ditawarkan oleh penyedia jaringan telekomunikasi. 
Dunia globalisasi yang semakin canggih, menuntut para pemimpin perusahaan berpikir secara rasional. Saat ini, keberadaan handphone menjadi salah satu faktor dimana kebutuhan manusia yang semakin hari semakin meningkat. Penggunaan handphone tidak akan terlepas dari yang namanya SIM Card, SIM Card kini telah menjadi salah satu kebutuhan pokok bagi pengguna handphone. Hal ini dapat menjadi peluang besar bagi para pembisnis yang berkelut dalam penyedia jaringan telekomunikasi seperti pada perusahaan Telekomunikasi Indonesia Selular (Telkomsel).

PT Telekomunikasi Indonesia Selular (Telkomsel) adalah suatu perusahaan yang bergerak di bidang penyediaan jasa telekomunikasi yaitu jasa telekomunikasi yang berbasis selular. Laju pertumbuhan ekonomi yang terus meningkat di seluruh daerah di Indonesia secara tidak langsung meningkatkan pertumbuhan konsumsi jasa selular yang ditawarkan perusahaan telekomunikasi ini. Untuk menunjang pelayanan terhadap pelanggan, PT Telkomsel membentuk struktur organisasi SHOP yang khusus melayani kebutuhan pelanggan yang bernama GraPARI.

Telkomsel merupakan pemimpin pasar industri telekomunikasi di Indonesia yang kini dipercaya melayani lebih dari 143 juta pelanggan pada tahun 2015-2016 dan sudah menjangkau sekitar 98\% wilayah populasi di Indonesia. Keberhasilan Telkomsel dalam memimpin pasar industri di Indonesia tidak terlepas dari strategi pemasaran yang baik. Menurut Hasan (2013:436), strategi pemasaran yang baik harus dibangun atas dasar pemahaman bisnis yang kuat, dikombinasikan dengan pemahaman kebutuhan dan keinginan pelanggan, pesaing dan skills, dan core bisnis termasuk dengan para pemasok dan distributor.

Perubahan-perubahan yang terjadi dalam dunia usaha mengharuskan perusahaan untuk merespon segala perubahan yang terjadi, masalah utama yang dihadapi perusahaan-perusahaan saat ini adalah bagaimana perusahaan menarik pelanggan dan mempertahankanya agar perusahaan tersebut dapat bertahan dan berkembang, tujuan tersebut akan tercapai jika perusahaan melakukan proses pemasaran. Pemasaran adalah salah satu kegiatan pokok yang dilakukan oleh perusahaan untuk mempertahankan kelangsungan hidupnya. Dengan semakin berkembangnya teknologi dan informasi saat ini, perusahaan di tuntut untuk lebih cermat dalam persaingan bisnis. Jika perusahaan ingin tetap eksis dalam persaingan, maka perusahaan harus memperhatikan salah satu fungsi pokoknya yaitu pemasaran. Menurut Kotler dan Keller (2009:38) pemasaran 
adalah proses perencanaan dan pelaksanaan konsepsi, penetapan harga, promosi dan distribusi gagasan barang dan jasa untuk menciptakan pertukaran yang memuaskan tujuan individu atau organisasi. Pada dasarnya loyalias pelanggan timbul karena kepuasan dari segi citra merek pada produk tersebut sehinggan menimbulkan rasa percaya konsumen terhadap produk yang bersangkutan dengan mempertimbangkan segala keputusan perusahaan dalam membangun citra merek tersebut.

Melihat kondisi persaingan yang ketat, hal utama yang perlu diperhatikan oleh perusahaan adalah citra merek (brand image) yang diberikan kepada para pelanggannya. Terjadinya perubahan pola pikir di masyarakat akan mempengaruhi perilaku pelanggan dalam melakukan pembelian. Pelanggan menjadi semakin kritis dalam memilih produk yang dibutuhkan yaitu dengan memilih produk yang paling unggul diantara produk sejenis yang ada. Selain itu para pelanggan saat ini mulai berani mengutarakan komplain, kritik dan sarannya terhadap perusahaan yang bersangkutan berkenaan dengan produk yang diberikan kepada para pelanggannya. Brand image memiliki hubungan dengan loyalitas, dimana pelanggan cenderung memilih berdasarkan citra merek, terutama ketika pelanggan itu tidak memiliki pengalaman dengan produk dalam kategori tertentu yang tidak pernah mereka beli, mereka akan cenderung untuk "percaya" pada produk dengan nama merek yang terkenal atau favorit (Schiffman \& Kanuk, 2007:485). Brand image yang baik akan menimbulkan kepercayaan (trust) dan loyalitas pelanggan terrhadap suatu produk, sehingga akan terjadi pembelian secara berulang-ulang.

Kepercayaan merupakan pondasi dari bisnis, membentuk kepercayaan konsumen merupakan cara untuk menciptakan dan mempertahankan konsumen. Menurut Moorman et. al. (2007:57), kepercayaan (Trust) adalah kesediaan (willingness) individu untuk menggantungkan dirinya pada pihak lain yang terlibat dalam pertukaran karena individu mempunyai keyakinan (confidence) kepada pihak lain tersebut.

Menurut Mowen dan Minor (2002:312), "kepercayaan konsumen (consumer beliefs) adalah semua pengetahuan yang dimiliki oleh konsumen dan semua kesimpulan yang dibuat konsumen tentang objek, atribut, dan manfaatnya”. Menurut Lau dan Lee (2007:344), “kepercayaan pelanggan pada merek (brand trust) didefenisikan sebagai keinginan pelanggan untuk bersandar pada sebuah merek pada resiko-resiko yang dihadapi karena ekspektasi terhadap merek itu akan menyebabkan hasil yang positif'. 
Guna mencapai pasar sasaran yang di tuju, perusahaan harus mampu membangun dan mempertahankan brand image dan trust sehingga tercipta loyalitas pelanggan. Loyalitas pelanggan merupakan salah satu tujuan inti yang diupayakan dalam pemasaran modern. Hal ini dikarenakan dengan loyalitas diharapkan perusahaan akan mendapatkan keuntungan jangka panjang atas hubungan mutualisme yang terjalin dalam kurun waktu tertentu. Menurut Hasan (2013:83) Loyalitas pelanggan didefinisikan sebagai orang yang membeli, khusunya yang membeli secara teratur dan berulang-ulang. Pelanggan merupakan seseorang yang terus menerus dan berulang kali datang ke suatu tempat yang sama untuk memuaskan keinginannya dengan memiliki suatu produk atau mendapatkan suatu jasa dan membayar produk atau jasa tersebut.

Berdasarkan teori pemasaran guna meningkatkan volume penjualan diatas, berikut ini letak produk Telkomsel pada tabel Top Brand Index.

\section{Tabel 1.}

Penjualan Produk SIM Card Berdasarkan TBI Tahun 2014-2016

\begin{tabular}{|c|c|c|c|c|c|c|c|c|}
\hline \multicolumn{2}{|c|}{ Produk SIM Card Tahun 2014} & \multicolumn{2}{|c|}{ Produk SIM Card Tahun 2015 } & \multicolumn{3}{|c|}{ Produk SIM Card Tahun 2016} \\
\hline Simpati & $30,2 \%$ & TOP & Simpati & $34.6 \%$ & TOP & Simpati & $35.5 \%$ & TOP \\
\hline IM3 & $16,9 \%$ & TOP & IM3 & $14.1 \%$ & TOP & IM3 & $15.4 \%$ & TOP \\
\hline $\begin{array}{c}\text { XL } \\
\text { Prabayar }\end{array}$ & $16,7 \%$ & TOP & $\begin{array}{c}\text { XL } \\
\text { Prabayar }\end{array}$ & $14.0 \%$ & TOP & $\begin{array}{c}\text { XL } \\
\text { Prabayar }\end{array}$ & $14.8 \%$ & TOP \\
\hline Kartu AS & $13,9 \%$ & & Kartu AS & $10.1 \%$ & & Tri '3' & $11.3 \%$ & \\
\hline Tri '3' & $8,9 \%$ & & Tri '3' & $9.0 \%$ & & Kartu AS & $10.4 \%$ & \\
\hline Axis & $8,1 \%$ & & Axis & $6.9 \%$ & & Axis & $5.1 \%$ & \\
\hline Mentari & $5,0 \%$ & & Mentari & $5,0 \%$ & & & & \\
\hline
\end{tabular}

Sumber : Data TBI (2017).

Berdasarkan dari data tabel 1. dapat dilihat bahwa Kartu As mengalami penurunan selama 2 tahun terakhir. Dimana pada tahun 2014 sebesar 13,9\%, tahun 2015 sebesar 10,1\%. Di tahun 2016 mengalami kenaikan sebesar 10,4\%. Dengan presentase penjualan yang fluktuatif setiap tahunnya, hal ini menunjukkan bahwa loyalitas pelanggan terhadap Kartu As pada tahun 2014-2015 mengalami penurunan dan pada tahun 2016 mengalami kenaikan.

Melihat fenomena diatas peneliti memfokuskan penelitian di Desa Pokaan Kecamatan Kapongan Kabupaten Situbondo maka tujuan dalam penelitian ini adalah sebagai berikut: 
1. Untuk mengetahui pengaruh variabel brand image dan trust berpengaruh secara parsial terhadap variabel loyalitas pelanggan pengguna kartu AS Telkomsel di Desa Pokaan Kecamatan Kapongan Kabupaten Situbondo.

2. Untuk mengetahui pengaruh variabel brand image dan trust berpengaruh secara simultan terhadap variabel loyalitas pelanggan pengguna kartu AS Telkomsel di Desa Pokaan Kecamatan Kapongan Kabupaten Situbondo.

3. Untuk mengetahui diantara variabel brand image dan trust yang paling berpengaruh dominan terhadap variabel loyalitas pelanggan pengguna kartu AS Telkomsel di Desa Pokaan Kecamatan Kapongan Kabupaten Situbondo.

\section{TINJAUAN PUSTAKA}

\section{Pemasaran}

Philip Kotler dan Keller (2008:5) mengemukakan bahwa pemasaran adalah suatu fungsi organisasi dan serangkaian proses untuk menciptakan, mengkomunikasikan, dan memberikan nilai kepada pelanggan dan untuk mengelola hubungan pelanggan dengan cara yang menguntungkan organisasi dan memangku kepentingannya. Menangani proses pertukaran ini membutuhkan banyak kerja dan keterampilan. Manajemen pemasaran terjadi ketika setidaknya satu pihak dalam sebuah pertukaran potensial berpikir tentang cara-cara untuk mencapai respon yang diinginkan pihak lain. Sedangkan Stanton yang dikutip Firdaus (2008:120) mengatakan bahwa pemasaran adalah suatu sistem keseluruhan dari kegiatan-kegiatan bisnis yang ditujukan untuk merencanakan dan menentukan harga, mempromosikan dan mendistribusikan barang atau jasa yang dapat memuaskan kebutuhan, baik kepada pembeli yang ada maupun pembeli potensial.

\section{Brand Image}

Menurut Kotler \& Keller (2009:288) merek merupakan nama, istilah, tanda, symbol, desain atau kombinasi dari beberapa elemen ini, yang dimaksudkan untuk mengidentifikasikan barang dan jasa dari satu atau sekumpulan penjual dan untuk mendiferensiasikan mereka dari para pesaingnya. Sedangkan Citra merek menurut Keller (2008:51) adalah persepsi konsumen tentang suatu merek sebagai refleksi dari asosiasi merek yang ada pada pikiran konsumen.

Menurut Rangkuti (2004:43) mendefinisikan "citra merek sebagai kumpulan asosiasi merek yang terbentuk di benak konsumen". Asosiasi merek sendiri merupakan segala hal yang berkaitan dengan ingatan mengenai suatu merek. Asosiasi ini merupakan 
atribut yang ada di dalam merek tersebut. Berbagai asosiasi yang diingat konsumen dapat dirangkai sehingga membentuk kesan terhadap merek (brand image).

\section{Kepercayaan}

Kepercayaan merupakan pondasi dari bisnis, membentuk kepercayaan konsumen merupakan cara untuk menciptakan dan mempertahankan konsumen. Menurut Moorman, et. al. (2007:52) kepercayaan (Trust) adalah kesediaan (willingness) individu untuk menggantungkan dirinya pada pihak lain yang terlibat dalam pertukaran karena individu mempunyai keyakinan (confidence) kepada pihak lain tersebut.

Menurut Mowen dan Minor (2002:312), "kepercayaan konsumen (consumer beliefs) adalah semua pengetahuan yang dimiliki oleh konsumen dan semua kesimpulan yang dibuat konsumen tentang objek, atribut, dan manfaatnya". Sedangkan menurut Lau dan Lee (2007:344), "kepercayaan pelanggan pada merek (brand trust) didefenisikan sebagai keinginan pelanggan untuk bersandar pada sebuah merek pada resiko-resiko yang dihadapi karena ekspektasi terhadap merek itu akan menyebabkan hasil yang positif'.

\section{Loyalitas Pelanggan}

Loyalitas pelanggan atau pelanggan merupakan fungsi dari kepuasan konsumen atau pelanggan. Menurut Tjiptono (2007:45) pada dasarnya tujuan dari bisnis adalah menciptakan para pelanggan yang merasa puas. Terciptanya kepuasan pelanggan dapat memberikan beberapa manfaat, diantaranya beberapa hubungan antara perusahaan dengan pelanggannya menjadi harmonis, memberikan dasar yang baik bagi pembelian ulang dan terciptanya loyalitas pelanggan dan membentuk suatu rekomendasi dari mulut ke mulut.

Menurut Tjiptono (2007:46) loyalitas merupakan komitmen pelanggan terhadap toko, merek ataupun pemasok yang didasarkan atas sikap positif yang tercermin dalam bentuk pembelian berulang secara konsisten. Menurut Durianto (2001:4), "konsumen yang loyal pada umumnya akan melakukan pembelian merek tersebut walaupun dihadapkan pada banyak alternatif merek produk pesaing yang menawarkan karakteristik produk yang lebih unggul dipandang dari berbagai sudutnya. Dipandang dari berbagai sudutnya atributnya. Bila banyak konsumen dari suatu merek masuk dalam kategori ini, berarti mereka tersebut memilliki ekuitas merek yang kuat. Ekuitas merek adalah seperangkat harta dan hutang merek yang terkait dengan suatun merek, nama, simbol 
yang mampu menambah atau mengurangi nilai yang diberikan oleh sebuah produk atau jasa baik pada perusahaan maupun pada pelanggan.

\section{Hipotesis}

Hipotesis adalah suatu jawaban yang bersifat sementara terhadap permasalahan penelitian, sampai terbukti melalui data yang terkumpul (Arikunto, 2006:71). Suatu hipotesis akan diterima apabila data yang dikumpulkan mendukung pernyataan, maka dalam hal ini hipotesis harus diuji kebenarannya. Berdasarkan rumusan masalah dan uraian di atas, maka hipotesis yang diajukan dalam penelitian ini adalah:

H1: Diduga variabel brand image dan trust berpengaruh secara parsial terhadap variabel loyalitas pelanggan pengguna kartu AS Telkomsel di Desa Pokaan Kecamatan Kapongan Kabupaten Situbondo.

H2: Diduga variabel brand image dan trust berpengaruh secara simultan terhadap variabel loyalitas pelanggan pengguna kartu AS Telkomsel di Desa Pokaan Kecamatan Kapongan Kabupaten Situbondo.

H3: Diduga variabel brand image berpengaruh paling dominan terhadap variabel loyalitas pelanggan pengguna kartu AS Telkomsel di Desa Pokaan Kecamatan Kapongan Kabupaten Situbondo.

\section{METODE PENELITIAN}

\section{Rancangan Penelitian}

Rancangan penelitian merupakan rancangan keseluruhan perencanaan dari suatu penelitian yang akan dilaksanakan dan akan dijadikan pedoman dalam melakukan penelitian. Metode penelitian pada dasarnya merupakan cara ilmiah untuk mendapatkan data yang valid dengan tujuan dapat ditemukan, dibuktikan dan dikembangkan suatu pengetauan sehingga pada gilirannya dapat digunakan untuk memahami, memecahkan dan mengidentifikasi masalah (Sugiyono, 2013:2). Pada penelitian ini menggunkan metode penelitian deskriptif dan kuantitatif.

\section{Populasi dan Sampel}

Populasi adalah wilayah generalisasi yang terdiri atas obyek/ subyek yang mempunyai kualitas dan karakteristik tertentu yang ditetapkan oleh peneliti untuk 
dipelajari kemudian ditarik kesimpulannya (Sugiyono, 2013:80). Populasi merupakan kumpulan individu atau objek penelitian yang memiliki kualitas serta ciri-ciri yang telah ditetapkan. Setelah melakukan observasi, populasi pada penelitian ini sebesar 685 pengguna kartu AS Telkomsel pada Desa Pokaan Kecamatan Kapongan Kabupaten Situbondo.

Adapun kriteria sampel yang diambil pada penelitian ini masyarakat Desa Pokaan Kecamatan Kapongan Kabupaten Situbondo yang menggunakan kartu AS Telkomsel, dengan jumlah sampel ditentukan berdasarkan pada perhitungan dari rumus Slovin dengan tingkat kesalahan yang ditoleransi sebesar 10\%. Berdasarkan rumus Slovin dan pertimbangan yang telah dikemukan, maka jumlah sampel yang digunakan dalam penelitian ini sebanyak 87 responden, dengan kriteria melakukan pembelian minimal sebanyak 3 kali kartu As.

\section{Identifikasi Variabel}

Menurut sugiyono (2013:38) variabel penelitian adalah suatu atribut atau sifat atau nilai dari orang, obyek atau kegiatan yang mempunyai variasi tertentu yang ditetapkan oleh peneliti untuk dipelajari dan kemudian di tarik kesimpulannya.

a. Variabel Bebas

Variabel bebas adalah variabel yang mempengaruhi variabel terikat, baik yang pengaruhnya positif maupun yang pengaruhnya negatif (Ferdinand, 2006:67). Variabel bebas dalam penelitian ini terdiri dari: Brand image (X1) dan Trust (X2)

b. Variabel Terikat

Variabel terikat merupakan variabel yang menjadi pusat perhatian peneliti (Ferdinand, 2006:67). Variabel terikat adalah variabel yang nilainya tergantung pada variabel lain, dimana nilainya akan berubah jika variabel yang mempengaruhinya berubah. Variabel terikat dalam penelitian ini adalah Loyalitas Pelanggan (Y).

\section{Uji Validitas}

Uji validitas dalam penelitian ini digunakan untuk menguji kevalidan kuesioner. Validitas menunjukkan sejauh mana ketepatan dan kecermatan suatu alat ukur dalam melakukan fungsi alat ukurnya. Uji validitas digunakan untuk mengetahui valid atau tidaknya suatu kuesioner. Suatu kuesioner dikatakan valid jika pertanyaan pada kuesioner mampu mengungkapkan suatu yang akan diukur oleh kuesioner tersebut (Ghozali, 2005:32). 


\section{Uji Reliabilitas}

Menurut Sugiyono (2004:124) uji reliabilitas adalah data untuk mengukur suatu kuesioner yang merupakan indikator dari variabel atau konstruk. Suatu kuesioner dikatakan reliabel atau handal jika jawaban seseorang terhadap pernyataan adalah konsisten atau stabil dari waktu ke waktu. Setiap alat pengukur seharusnya memiliki kemampuan untuk memberikan hasil pengukuran yang konsisten. Makin kecil kesalahan pengukuran, makin reliabel alat pengukur.

\section{Analisis Regresi Linear Berganda}

Analisis ini digunakan untuk mengetahui seberapa besar pengaruh variabel bebas yaitu brand image $\left(\mathrm{X}_{1}\right)$ dan trust $\left(\mathrm{X}_{2}\right)$ terhadap variabel terikat yaitu loyalitas pelanggan (Y) di Desa Pokaan Kecamatan Kapongan Kabupaten Situbondo. Menurut Sugiyono, (2010:275) untuk mengetahui pengaruh variabel bebas terhadap variabel terikat digunakan rumus analisis regresi linier berganda sebagai berikut:

$$
Y=\alpha+b_{1} x_{1}+b_{2} x_{2}+e
$$

\section{Koefisien Determinasi}

Koefisien determinan merupakan besaran yang memberikan informasi mengenai proposi variasi dalam variabel terikat oleh variabel bebas (Gujarati, 2000:99).

\section{HASIL DAN PEMBAHASAN Uji Validitas}

Validitas menunjukkan sejauh mana alat pengukur mampu mengukur apa yang ingin diukur dalam sebuah penelitian, oleh sebab itu, kuesioner dalam penelitian ini pun harus diuji validitasnya, apakah kuesioner valid dan dapat digunakan sebagai instrumen pengumpulan data atau kuesioner tidak valid sehingga tidak mampu memberikan informasi dan hal yang ingin diukur dalam penelitian ini. Untuk menguji validitas setiap butir maka skor dari masing-masing butir dimaksud dikorelasikan dengan total skor. Hasil perhitungan uji validitas menunjukkan bahwa semua variabel penelitian valid dikarenakan nilai r_hitung lebih besar dari r_tabel.

\section{Uji Reliabilitas}

Reliabilitas adalah tingkat kepercayaan hasil suatu pengukuran. Pengukuran yang memiliki reliabilitas tinggi, yaitu pengukuran yang mampu memberikan hasil ukur yang 
terpercaya (reliabel). Walaupun secara teoritis besarnya koefisien reliabilitas sekitar 0,00 s/d 1,00, akan tetapi pada kenyataannya koefisien sebesar 1,00 tidak pernah tercapai dalam pengukuran, karena manusia sebagai subjek penelitian merupakan sumber error yang potensial.

Nilai reliabilitas variabel pada tabel diatas memberikan indikasi bahwa kehandalan kuisioner yang digunakan sebagai alat pengukur termasuk pada kategori berkorelasi kuat untuk tiap variabel tersebut. Uji reliabilitas ini memberikan indikasi bahwa kehandalan kuisioner yang digunakan sebagai alat pengukur untuk tiap variabel termasuk pada kategori berkorelasi tinggi dan diterima, karena setiap nilai alpha melebihi nilai Alpha Cronbach yaitu 0,70 maka semua variabel adalah reliabel.

\section{Analisis Regresi Linier Berganda}

Berdasarkan data penelitian yang dikumpulkan baik untuk variabel terikat (Y) maupun variabel bebas $\left(\mathrm{X}_{1}, \mathrm{X}_{2}\right)$ yang diolah menggunakan bantuan program SPSS 22 for Windows 13. Berdasarkan hasil perhitungan analisis regresi dapat diperoleh persamaan regresi linier berganda sebagai berikut: $\mathrm{Y}=3,687 \mathrm{E}-16+0,510 \mathrm{X}_{1}+0,254 \mathrm{X}_{2}+e$

\section{Koefisien Determinasi $\left(\mathbf{R}^{2}\right)$}

Koefisien determinasi digunakan untuk mengetahui kemampuan variabel independen dalam menjelaskan variabel dependen. Besarnya determinasi dapat dilihat pada R Square dan dinyatakan dalam presentase. Hasil dari analisis pengaruh brand image $\left(\mathrm{X}_{1}\right)$ dan truts $\left(\mathrm{X}_{2}\right)$ terhadap loyalitas pelanggan $(\mathrm{Y})$ seperti pada tabel diatas, menunjukkan nilai koefisien determinasi atau R square menunjukkan nilai sebesar 0,524, dari hasil tersebut berarti seluruh variabel bebas (brand image dan truts) mempunyai kontribusi sebesar 52,4\% terhadap variabel terikat (loyalitas pelanggan) dengan tingkat ketetapannya cukup, dan sisanya sebesar $47,6 \%$ dipengaruhi oleh faktor-faktor lain yang tidak masuk dalam penelitian.

\section{Pembahasan}

\section{Pengaruh Citra Merek (Brand Image) Terhadap Loyalitas Pelanggan}

Hasil analisis menunjukkan brand image berpengaruh positif signifikan terhadap loyalitas pelanggan. Berdasarkan pengujian tersebut maka dapat disimpulkan bahwa hipotesis pertama yang menyatakan ada pengaruh secara parsial antara brand image terhadap loyalitas pelanggan pada pengguna kartu As Telkomsel di Desa Pokaan Kecamatan Kapongan Kabupaten Situbondo adalah diterima. Hasil ini mengindikasikan 
bahwa jika persepsi konsumen tentang citra merek (brand image) kartu As Telkomsel meningkat maka loyalitas pelanggan juga akan meningkat, dan sebaliknya jika persepsi konsumen tentang citra merek (brand image) kartu As Telkomsel maka loyalitas pelanggan juga akan menurun. Citra merek (brand image) adalah variabel yang paling dominan mempengaruhi loyalitas pelanggan.

Hasil penelitian menunjukan bahwa pengguna kartu As Telkomsel di Desa Pokaan sebagai responden dalam penelitian ini telah mengakui brand image yang dimiliki kartu As Telkomsel. Pada dasarnya persepsi responden terbentuk dari pernyataan yang telah disetujui mengenai brand image kartu As Telkomsel. Responden pengguna kartu As Telkomsel di Desa Pokaan memiliki persepsi yang pertama merasa kartu AS telah dikenalai konsumen. Kedua, merasa kartu AS memiliki model yang up to date. Ketiga, merasa kartu AS memiliki manfaat dan digunakan sesuai kebutuhan. Keempat, merasa kartu AS menjadi salah satu merek sim card terpopuler. Pernyatan tersebut menunjukan bahwa persepsi mengenai brand image kartu As Telkomsel mampu mempengaruhi loyalitas pelanggan sehingga pengguna kartu As Telkomsel di Desa Pokaan sebagai responden akan menimbulkan rasa kepercayaan dan loyalitas yang tinggi pada kartu As Telkomsel.

Argumen logis dan rasional terhadap diterimanya hipotesis pertama tersebut adalah terkait dengan persepsi konsumen atas citra merek (brand image) yang terbentuk dari kartu As Telkomsel. Hasil penelitian ini sesuai dengan pernyataan Keller (2005:27), bahwa keterkaitan antara citra merek (brand image) dengan loyalitas pelanggan pada dasarnya citra merek (brand image) yang positif dapat meningkatkan kemungkinan pilihan terhadap merek (brand) tersebut. Asosiasi citra merek (brand image) menjadi pijakan dalam keputusan konsumen untuk loyal terhadap merek (brand) tersebut. Orang yang sudah loyal tidak dapat melihat merek (brand) lain karena pada dasarnya konsumen akan percaya pada merek (brand) produk yang sudah mereka kenal sebelumya, bahkan mereka bisa memilih begitu saja secara optimis brand yang mereka kenal tanpa usaha membandingkan dengan merek (brand) lain. Dengan demikian hasil penelitian ini sejalan dengan hasil penelitian yang dilakukan oleh Retno Budi Lestari pada tahun 2014, yang menemukan bahwa variabel citra merek (brand image) berpengaruh secara parsial terhadap loyalitas pelanggan Handphone XYZ Di Palembang. 


\section{Pengaruh Kepercayaan (trust) Terhadap Loyalitas Pelanggan}

Hasil analisis menunjukkan kepercayaan (trust) berpengaruh positif signifikan terhadap loyalitas pelanggan. Berdasarkan pengujian tersebut maka dapat disimpulkan bahwa hipotesis pertama yang menyatakan ada pengaruh secara parsial antara kepercayaan (trust) terhadap loyalitas pelanggan pada pengguna kartu As Telkomsel di Desa Pokaan Kecamatan Kapongan Kabupaten Situbondo adalah diterima. Hasil ini mengindikasikan bahwa jika persepsi konsumen tentang kepercayaan (trust) kartu As Telkomsel meningkat maka loyalitas pelanggan juga akan meningkat, dan sebaliknya jika persepsi konsumen tentang kepercayaan (trust) kartu As Telkomsel maka loyalitas pelanggan juga akan menurun.

Hasil penelitian menunjukan bahwa pengguna kartu As Telkomsel di Desa Pokaan sebagai responden dalam penelitian ini telah mengakui kepercayaan (trust) yang dimiliki kartu As Telkomsel. Pada dasarnya persepsi responden terbentuk dari pernyataan yang telah disetujui mengenai kepercayaan (trust) kartu As Telkomsel. Responden pengguna kartu As Telkomsel di Desa Pokaan memiliki persepsi yang pertama merasa kartu AS memiliki konsistensi dalam membangun kepercayaan konsumen. Kedua, merasa kartu AS telah berhasil membangun kepercayaan di benak konsumen. Ketiga, merasa kartu AS dapat menyelesaikan masalah yang terjadi pada konsumen. Pernyatan tersebut menunjukan bahwa persepsi mengenai kepercayaan (trust) kartu As Telkomsel mampu mempengaruhi loyalitas pelanggan sehingga pengguna kartu As Telkomsel di Desa Pokaan sebagai responden akan menimbulkan loyalitas pada kartu As Telkomsel.

Argumen logis dan rasional terhadap diterimanya hipotesis pertama tersebut adalah terkait dengan persepsi konsumen kepercayaan (trust) yang terbentuk dari kartu As Telkomsel. Hasil penelitian ini sesuai dengan pernyataan Barnes (2003:148) kepercayaan adalah keyakinan bahwa seseorang akan menemukan apa yang ia inginkan pada diri orang lain, dan bukan apa yang ia takutkan. Kepercayaan melibatkan kesediaan seseorang untuk bertingkah laku tertentu karena keyakinan bahwa partnernya akan memberikan kepuasan yang ia harapkan dan suatu harapan yang umumnya dimiliki seseorang bahwa kata, janji, atau pernyataan orang lain dapat dipercaya. Dengan demikian hasil penelitian ini sejalan dengan hasil penelitian yang dilakukan oleh Sutrisni pada tahun 2010, yang menemukan bahwa variabel kepercayaan (trust) berpengaruh 
secara parsial terhadap loyalitas pelanggan Indosat Im3 Pada Mahasiswa Fakultas Ekonomi Universitas Diponegoro Semarang.

\section{SIMPULAN DAN SARAN}

\section{Simpulan}

a. Hasil uji statistik secara parsial atau uji t menunjukkan nilai $t_{\text {hitung }}$ untuk variabel brand image sebesar 4,329. Sementara itu nilai pada $t_{\text {tabel }}$ distribusi $5 \%$ sebesar 1,988, maka $t_{\text {hitung }} 4,329>t_{\text {tabel }} 1,988$, nilai signifikan $0,000<0,05$. Kesimpulannya variabel brand image mempunyai pengaruh signifikan positif terhadap loyalitas pelanggan. Nilai $t_{\text {hitung }}$ untuk variabel truts ini sebesar 2,154. Sementara itu nilai pada $t_{\text {tabel }}$ distribusi $5 \%$ sebesar 1,988, maka $t_{\text {hitung }} 2,154>$ $\mathrm{t}_{\text {tabel }} 1,988$, nilai signifikan $0,034<0,05$. Kesimpulannya variabel truts berpengaruh secara signifikan positif terhadap loyalitas pelanggan.

b. Hasil uji statistik secara simultan atau uji $F$ menunjukkan nilai $F_{\text {hitung }}$ sebesar 46,226, sedangkan nilai pada $F_{\text {tabel }}$ sebesar 3,11, maka $F_{\text {hitung }}>F_{\text {tabel }}$. Berdasarkan pengujian statistik dengan menggunakan metode uji $\mathrm{F}$, dimana tingkat signifikan yang diperoleh $0,000<0,05$, maka dapat disimpulkan bahwa hipotesis penelitian (Ha) yang menyebutkan bahwa brand image dan truts terhadap loyalitas pelanggan pada pengguna kartu As di Desa Pokaan dapat diterima.

c. Hasil uji statistik secara dominan menunjukkan nilai pengaruh positif variabel bebas terhadap variabel terikat, dengan nilai pengaruh variabel brand image $\left(\mathrm{X}_{1}\right)$ sebesar 4,329 dan truts $\left(\mathrm{X}_{2}\right)$ sebesar 2,154, maka kesimpulannya adalah nilai dari variabel brand image tersebut lebih besar dari variabel truts yaitu sebesar 4,329 dengan demikian, hipotesis penelitian $\left(\mathrm{H}_{3}\right)$ yang menyatakan bahwa variabel brand image berpengaruh paling dominan terhadap loyalitas pelanggan dapat diterima.

\section{Saran}

Berdasarkan hasil kesimpulan yang telah diuraikan maka dapat diberikan saransaran yang dapat dijadikan sebagai bahan pertimbangan bagi perusahaan, yaitu:

1. Pihak PT. Telkomsel harus lebih meningkatkan citra merek dan kepercayaan terhadap produk-produk yang dihasilkan khususnya pada kartu As, karena hal ini akan lebih meningkatkan loyalitas pelanggannya. PT. Telkomsel harus terus berupaya 
meningkatkan citra merek dan kepercayaan pelanggannya, baik dengan cara terus menjaga kualitas produknya, kualitas pelayanan dan harga yang ditawarkan pada produk maupun hal yang lain yang bisa menumbuhkan atau meningkatkan citra merek dan rasa percaya pelanggannya untuk terus menjaga pelanggannya atau bahkan menambah jumlah pelanggannya. Terutama pada kalangan anak muda dan remeja yang dikira akan jauh lebih cepat meningkat, karena pangsa pasar kalangan anak muda dan remaja saat ini sudah semakin besar, hal ini bisa dilihat dari lingkungan sekitar bahwa anak SD saja sudah menggunakan telpon genggam. Hal ini harus menjadi target yang harus dicapai dan dikuasai oleh pihak PT. Telkomsel agar perusahaan terus menjadi pemimpin pasar pada penjualan SIM Card seluler.

2. Penulis yang berfokus pada objek yang sama harus lebih mempertimbangkan keadaan dan kondisi pada saat itu, agar mampu memperoleh dan memahami hasil penelitian sesuai dengan yang diinginkan dan mampu menjawab dari permasalahan yang ada, terutama pada variabel-variabel yang sama dengan penelitian ini.

\section{DAFTAR PUSTAKA}

Akbar dan Parvez. 2009. Intisari Pemasaran dan Unsur-Unsur Pemasaran. Edisi Ketiga. Bandung: Indah Karya.

Arikunto, S. 2010, Prosedur Penelitian, ed. Rev.,cet. Empat Belas. PT Rineka Cipta: Jakarta.

Augusty, F. 2006. Metode Penelitian Manajemen. Semarang: Badan Penerbit Universitas Diponegoro.

Barnes. 2003. Rahasia Manajemen Hubungan Pelanggan. Yogyakarta: Andi Offset.

Budi Lestari, Retno. 2014. Pengaruh Brand Image, Brand Trust, dan Company Reputation Terhadap Loyalitas Handphone XYZ Di Palembang. Diterbitkan. Skripsi. Palembang: STIE MDP.

Djati, P. dan Ferrinadewi. 2004. Perilaku Konsumen dan Komunikasi Pemasaran. Cetakan Ketiga. Bandung: PT. Remaja Rosdakarya.

Durianto. 2001. Bauran Pemasaran dan Loyalitas Konsumen. Cetakan Pertama. Bandung: Alfabeta.

Gujarati, D. 2000. Dasar-dasar Ekonometrika. Jakarta: Erlangga. 
Ghozali, I. 2016. Aplikasi Analisis Multivariate Dengan Program SPSS. Semarang: Badan Penerbit Universitas Diponegoro.

Griffin, Jill. 2005, Customer Loyalty, Edisi Revisi, Jakarta : Erlangga.

Kasali, R. 2005. Manajemen Public Relations, Konsep dan Aplikasinya di Indonesia. Jakarta : Pustaka Utama Grafiti.

Keller. 2008. Manajemen Pemasaran. Edisi 14. Global Edition. Hall: Pearson Prentice.

Kotler, P. 2005. Manajemen Pemasaran, jilid 1, Jakarta: PT. Indeks Kelompok Gramedia.

Kotler, P. \& Keller, K. L. 2009. Manajemen Pemasaran, Edisi 13 jilid 1. Jakarta: Penerbit Erlangga

Kurniawati, D. 2014. Pengaruh Citra Merek Dan Kualitas Produk Terhadap Kepuasan Dan Loyalitas Pelanggan (Studi Pada Pelanggan Kfc Cabang Kawi Malang). Diterbitkan. Skripsi. Malang: Universitas Brawijaya.

Lupiyoadi, R. 2008. Manajemen Pemasaran Jasa, Edisi 2. Jakarta: Salemba Empat.

Low dan Lamb. 2007. Dasar-Dasar Pemasaran. Kudus: Badan penerbit Universitas Muria Kudus

Lau dan Lee. 2007. Prinsip Pemasaran. Jakarta: PT Gelora Aksara Pratama.

Hasan, A. 2013. Marketing. Yogyakarta: Media Utama

Husein, U. 2004. Metode Penelitian Untuk Skripsi dan Tesis Bisnis, Cetakan ke 6. Jakarta: PT Raja Grafindo Aksara.

Machfoedz, M. 2010. Komunikasi Pemasaran Modern. Yogyakarta: Cakra Ilmu.

Mohammad. 2011. Strategi Dalam Manajemen Pemasaran. Jakarta: Badan Penerbit IPWI.

Moorman, et. al. 2007. Manajemen Pemasaran. Terjemahan Sumarno Zain. Jakarta: Erlangga.

Mowen, J. C., dan Minor, M. 2002. Perilaku konsumen. Trans.( Lina Salim). Jakarta: Erlangga.

Nurani, A. 2015. Pengaruh Brand Image, Trust dan Kualitas Produk Terhadap Loyalitas Pelanggan Indomie. Diterbitkan. Skripsi. Semarang: Universitas Dian Nuswantoro. 
Prasetyo, W. B. 2014. Pengaruh Kualitas Pelayanan, Kepercayaan Dan Kepuasan Terhadap Loyalitas Pelanggan (Studi Pada Swalayan Luwes Purwodadi). Diterbitkan. Skripsi. Semarang: Universitas Diponogoro.

Rangkuti, F. 2004. Riset Pemasaran. Cetakan 5. Jakarta: PT. Gramedia Pustaka Utama.

Roslina. 2010. Dasar-Dasar Pemasaran. Jakarta: PT Raja Grafindo Persada.

Schiffman, L, G., Kanuk. L. L. dan Leslie L. 2006. Prilaku Konsumen, Diterjemahkan oleh Zulkifli Kasip. Jakarta. Penerbit: PT Indeks.

Schiffman, L, G. dan, L. L. Kanuk. 2007. Persepsi kualitas, Consumer Behavior. New Jersey: Perason Prestice Hall.

Sugiyono. 2013. Metode Penelitian Kuantitatif, Kualitatif, dan R\&D. Bandung: CV. Alfabeta.

Sutrisni. 2010. Analisis Pengaruh Kualitas Produk, Kualitas Pelayanan, Desain Produk, Harga Dan Kepercayaan Terhadap Loyalitas Pelanggan Indosat Im3 Pada Mahasiswa Fakultas Ekonomi Universitas Diponegoro Semarang. Diterbitkan. Skripsi. Semarang: Universitas Diponogoro.

Swastha, B. dan Irawan. 2003. Manajemen Pemasaran Modern Analisis Perilaku Konsumen. Yogyakarta: Liberty.

Swastha, Basu. 2005. Azas-azas Marketing. Yogyakarta : Liberty.

Tjiptono, F. 2008. Strategi Pemasaran, edisi kedua, cetakan dua, Yogyakarta : Andi.

Viot. 2007. Manajemen Penerapan Konsep-Konsep Kualitas dalam Manajemen Bisnis Total. Jakarta: Penerbit Gramedia Pustaka Utama.

Yin, Y. dan Faziharudean. T.M. 2010. Factor Affecting Custommer Loyalty of Using Internet Banking in Malaysia. Jounal of Electronic Banking System Faculty of Businees and Accountancy. University of Malaysia. 